\title{
ATM Service Quality and its Effect on Customer Retention: A Case from Pakistani Banks
}

\author{
*Ameer Hasan ${ }^{1}$, Usman Asif ${ }^{1}$, Muhammad Irfan Arif², Nimra Khan ${ }^{3}$ \\ ${ }^{1}$ Riphah International University Islamabad, Pakistan \\ ${ }^{2}$ University of Education Lahore, Pakistan \\ ${ }^{3}$ Khan Homes Sargodha, Pakistan \\ *euphoric.ameer@gmail.com
}

\begin{abstract}
The concept customer retention has received a considerable attention from a few decades in both areas as academic and industry. In the dynamic market environment, customer retention is seen as much important factor to compete in the market. Banks deals very closely to their customers, find, and fulfill their needs. Due to the technological advancement, banks are offering technology based services to the customers, the aim is to have a competitive advantage in satisfying their customer needs and hence to retain their customers. This research attempts to find the technology based ATM service quality, that how the customer are satisfied with it and hence being retained with the bank. The study will find the factor of ATM service quality that are helpful in retaining the customers. Data was collected from different banks of Pakistan and result depicts that the satisfaction of the bank customers with ATM service quality leads to retain the customer with the bank. Hence, the manger should need to focus on the quality ATM service to their customers, to retain their customers with the Banks.
\end{abstract}

Keywords: ATM, Service Quality, Customer Satisfaction, Customer Retention

\section{Introduction}

Advancement in Technology and communication the service industry found the different channels of delivery for providing the best services to their customers. Electronic delivery channels are widely accepted in business and also in public for providing the best services to customers for interaction and communication (Parasuraman and Zinkhan, 2002; Bauer, Hammerschmidt and Falk, 2005). E-banking brought great changing in banking industry. One of the latest and widely accepted distribution channels to be used in the financial services organizations is electronic banking; it was established in the mid 1990s, after that steadily becoming more imperative (Allen et al, 2001). Researchers have classified the electronic banking into three sections, Internet Banking, Telephone Banking and Automated Teller Machin (Joseph and Stone, 2003; Ibrahim, Joseph and Ibeh, 2006). ATM card is the most frequent instrument use in electronic channel services of bank. ATM service plays a significant role in customer satisfaction in banking (Premalatha \& Sundaram, 2012). ATM is innovative electronic delivery channel, which offers different financial services like Cash withdraw, payments of utility bills, and credit cards, transfer of funds etc (Pawa \& Saxena, 2011). ATM service quality and customer satisfaction was investigated in banks of Pakistan in which the impact of service quality of ATM on customer satisfaction examined (Khan, 2010). In Iran, the service quality impacts on customer loyalty were found in which the dimensions of perceived quality service was scrutinized (Mosahab et al, 2010). Moreover, the customer perception about ATM service quality was measured in Ghana (Narteh, 2013). Customer satisfaction has significant relationship with customer retention because satisfied customer retain with the organization. While the unsatisfied customer from the services received from organization, would no long have relation with the organization Wu \& Wang, (2007)? Most of the prior studies were conducted on service quality, perceived service quality dimensions, customer perception, customer satisfaction and service loyalty (Khan, 2010; Mosahab et al, 2010; Narteh, 2013). ATM Service quality, customer satisfaction and customer retention has not explored ever before (Khan, 2010: Narteh, 2013). ATM users are increasing rapidly owing to this it is compulsory for baking management to understand the demands of customers about the features of ATM service. This study is very helpful to find out the positive and negative responses and features required by the customers for satisfaction and retention. The bank management can make decisions for improving and maintaining the ATM service quality. 


\section{Literature Review}

Service quality is determined by the difference between service providers and customer's expectation about the performance and evaluation of service received by customers (Parasuraman, Zeithaml and Berry, 1985; Parasuraman et al., 1988). Electronic service quality is a key determinant in differentiating service offers and building competitive advantage because the cost of comparing alternatives are relatively low in online environments (Santos, 2003; Bauer et al., 2005). Service quality was a multidimensional variable. It has 22 attributes (Parasuraman, Zeithaml and Berry, 1985; Parasuraman et al., 1988). The seven dimensions of ATM service quality were used in the study Narteh (2013). Automated service quality is defined as the customer's overall evaluation of the excellence of the provision of services through electronic networks such as the internet, Automated Teller Machine (ATM), and telephone banking (Santos, 2003). ATM as an electronic device which help customers to deposit, withdraw, transfer money, pay bills and perform other financial transactions outside the branch. From the prior, it is argued that ATM is the electronic versions of the brickand-mortar banking halls and customers visit the ATM to perform financial transactions. The ability of the ATM to perform these functions to the satisfaction of customers will measure ATM service quality. The study, therefore, defines ATM service quality as the customers' overall evaluation and judgment of the excellence of services provided through ATM channels. Electronic banking service quality have followed the view that customers use electronic banking channels in a complementary way and therefore, their service quality dimensions were jointly determined in a single study (Jospeh and Stone, 2003; Al-Hawari and Ward, 2006) Mols (2000) argued that customer acceptance of the new automated channels of service delivery in banks may bring a dramatic change in the way that retail banks build and maintain a close relationship with their customers. Moreover, many researchers have described a positive link between service quality and customer retention (Bansal and Taylor, 1999; Brady et al., 2002; Fullerton and Taylor, 2002; Roos, 1999; Rust et al., 1995; Zeithaml et al., 1996).

\section{H1- ATMSQL has positive association on customer Retention.}

Customer satisfaction is a key factor in development of customer's desires for future purchase (Mittal \& Kamakura, 2001). Furthermore, the satisfied customers will probably share their good experiences with others especially in Middle Eastern cultures (Jamal \& Naser, 2002). Customer satisfaction has been defined as the difference between expectation and performance of organization is offering, but there are differences between quality and satisfaction. Satisfaction determined after experience that quality is the same or not (Parasuraman et al. 1991). Prior studies have been done on the relation between service quality and satisfaction: findings of some of these researches show that satisfaction results in service quality (Parasuraman et al., 1988). Research conducted by Sureshchandar et al. (2002) describes that, there is a twoway relation between satisfaction and service quality.

\section{H2-ATMSQL has positive association on customer satisfaction.}

However, the customers only retain when they are satisfied from the products and services of the organization. Customer retention management indicated that customer retained if three conditions fulfilled (customer satisfied from the organizational products/services, customer had intention to continue relation with organization \& customer highly recommend your products/services to others) Alshurideh et al. (2012)

\section{H3- Customer satisfaction has positive association with customer retention. H4- Customer satisfaction mediates the relationship between ATM service quality and customer retention.}

Fig 1: Theoretical Framework

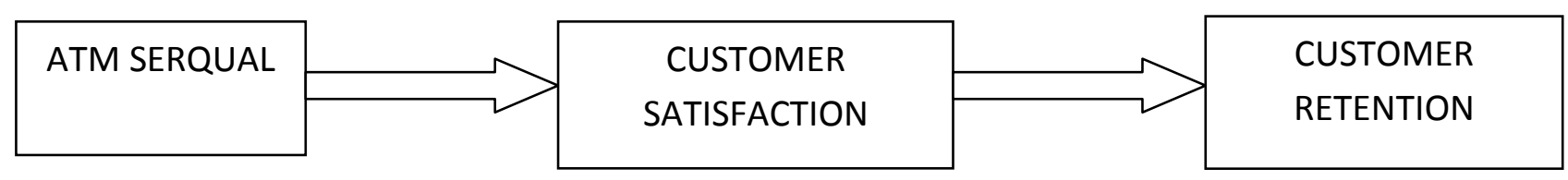




\section{Methodology}

The study was self-administered survey was conducted to analyze the ATM Service quality, customer satisfaction on customer retention from Bank customers. ATM SQUAL questionnaire was adopted from Joseph and Stone, (2003), Collier and Bienstock, (2006), Wolfbinbarger and Gilly, (2003); Al-Hawari et al., (2005); Lee and Lin, (2005); Khan, (2010); Katono (2011). However, the customer satisfaction \& retention were adopted from (Anderson, \& Sullivan, 1993; Fornel, 1992; Levesque, \& McDougall, 1996). Five points likert-scale was used for data collection. The target audience is from ATM user of different banks of Pakistan from two cities, Mianwali and Sargodha. A total 240 questionnaire were distributed to the ATM users, of which 214 (170 male \& 44 female) were useful. Non-Probability random sampling in the form of convenience sampling was used to collect the data. The purpose for using this specific sampling method was due to the respondents being easily available \& accessible, as well as it being less time consuming and inexpensive to gather the required data. Researches stated that "the advantage of non-probability samples is that they are less complicated and more economical than probability samples.

\section{Results and Discussion}

Table 1: Results of Correlations

\begin{tabular}{lllllll}
\hline S. No. & Name & Mean & S.D & Servqual & C-satisfaction & C-retention \\
\hline 1 & Servqual & 3.36 & .537 & $(.884)$ & & \\
2 & C-satisfaction & 3.60 & .945 & $.135^{*}$ & $(.706)$ &. \\
3 & C-retention & 3.27 & .926 & $.680^{* *}$ & $.448^{* *}$ & $(.846)$ \\
\hline
\end{tabular}

*. Correlation is significant at the 0.05 level (2-tailed). $\quad(n=214)$

**. Correlation is significant at the 0.01 level (2-tailed).

The above table describe that the relationship between the variables. In the above table it clear that service quality of ATM has a significant relationship with customer satisfaction, the value indicate $(r=.135, \mathrm{p}<0.05)$ that the service quality and customer satisfaction has positive relationship. On contrary, it clears that ATM service quality and customer satisfaction is no strong relationship. The table describe that SERQUL and customer retention's value is $(\mathrm{r}=.680, \mathrm{p}<0.05)$ which states that SERQUL and customer retention has positive and strong relationship. The value of customer satisfaction and customer retention in table $(\mathrm{r}=.448, \mathrm{p}<0.05)$ which indicates that the customer satisfaction and customer retention has positive association, however the relationship is no strong. The above correlation table show that our hypothesis is in line and in positive direction.

Table 2: Regression Results Coefficients $^{\mathbf{a}}$

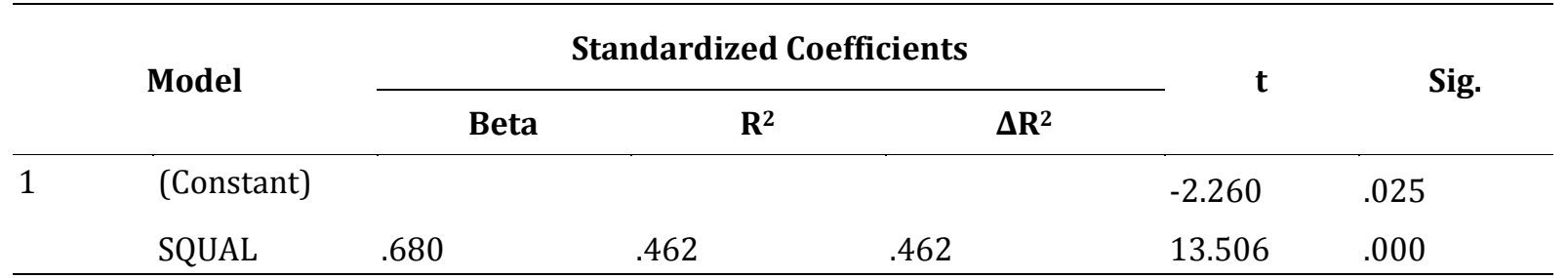

a. Dependent Variable: c-Retention

Table 2 shows that ATM SERQUAL is significant and positive association with customer retention. It describe that value of ATMSQL is $(B=.680 \mathrm{R} 2=.462, \mathrm{p}<0.05)$ positive and significant. So it supports the hypotheses and H1 accepted. 
Table 3: Regression Results

Coefficients ${ }^{\mathbf{a}}$

\begin{tabular}{lllllll}
\hline \multirow{2}{*}{ Model } & & \multicolumn{2}{c}{ Standardized Coefficients } & \multicolumn{1}{c}{ Sig. } \\
\cline { 3 - 7 } & & Beta & $\mathbf{R}^{2}$ & $\mathbf{\Delta R}^{2}$ & \\
\hline 1 & (Constant) & & & & 6.883 & .000 \\
& SQUAL & .135 & .120 & .120 & 1.981 & .049 \\
\hline
\end{tabular}

a. Dependent Variable: c-Satisfaction

Table 3 show that there is significant association of ATMSQL on customer satisfaction, the values (B=.135, R2 $=.120, \mathrm{p}<0.05$ ) show that if 1 unit of ATMSQL change then the customer satisfaction changing rate is $13.5 \%$ which is significant. It supports the hypotheses and $\mathrm{H} 2$ accepted.

\section{Table 4: Regression Results} Coefficients ${ }^{\mathrm{a}}$

\begin{tabular}{lllcccc}
\hline \multirow{2}{*}{ Model } & & \multicolumn{2}{c}{ Standardized Coefficients } & t & Sig. \\
\cline { 3 - 5 } & & Beta & $\mathbf{R}^{2}$ & $\mathbf{\Delta R}^{2}$ & & \\
\hline 1 & (Constant) & & & & 7.551 & .000 \\
& C-satisfaction & .448 & .201 & .201 & 7.295 & .000 \\
2 & (Constant) & & & & -5.833 & .000 \\
& C-satisfaction & .363 & & & 8.174 & .000 \\
& SERVQUAL & .631 & .592 & .391 & 14.217 & .000 \\
\hline
\end{tabular}

a. Dependent Variable: c-retention

Table 4 indicates that the customer satisfaction and customer retention has positive association and significant relationship. The value of the table $\left(B=.448, \mathbf{R}^{2}=.201, \mathrm{p}<0.05\right)$ support the hypotheses and $\mathrm{H} 3$ accepted. However in the table the value indicated $\left(B=.631, \mathbf{R}^{2}=.592\right.$,

$\left.\Delta \mathbf{R}^{2}=.391, \mathrm{p}<0.05\right)$ that customer satisfaction partially mediate the relationship between SERQUAL and customer retention. So it supports the hypotheses and $\mathrm{H} 4$ accepted.

Discussion of results: The literature on electronic service quality postulates that the delivery of high service quality is an important factor for achieving high customer satisfaction (Fassnacht and Koese, 2006; Khan, 2010). This study was conducted to determine the dimensions of ATM service quality of the relative importance of the dimensions in predicting over all ATM quality. The study revealed in order of importance a five-factor structure referred to as ATMqual which was used in the Ghanaian banking industry (Nareth, 2013). The dimensions of the ATMqual model were reliability, responsiveness, convenience, ease of use and fulfillment. The ATM quality dimensions "ease of use" and "convenience" are different from the service quality dimensions found in traditional services such as reliability, assurance, responsiveness, empathy and tangibles proposed by the SERVQUAL framework (Parasuraman et al., 1988). This resonates with views from (Parasuraman et al., 2005; Zeithaml et al., 2002) that electronic banking service quality dimensions might be unique and should be addressed differently from traditional service quality dimensions as proposed in the extant literature. On the quality dimensions, customers first expect their ATM to be reliable. Reliability connotes the ability of the ATM to function all the time and deliver what it promises to do. The customers expect the ATM to remain functional, provide error-free services as well as give consistent services. (Parasuraman et al., 1988; Wolfinbarger and Gilly, 2003; Fassnacht and Koese, 2006; Khan, 2010). 
Customer satisfaction has direct effects on customer retention. As the customers satisfied from the organizational products they retained and they recommend to others for usage of the products and services. Anderson and Sullivan (1993). Service quality enhances the customer satisfaction, which also play an important role in customer retention (Kandampully, 1998).

\section{Recommendations and Managerial Implication}

The managers of banking industry focus on ATM service quality because ATM SERVQUL has integral part of customer retention. In these days the ATM is a compulsory and important service in these days. The managers of banking industry give special concentration on providence of ATM SERVQUAL so that customer retain with bank. Managers of different banks assure the quality of ATM for providing the best service to customer for long-term relationship.

Limitations \& Direction for future Studies: This study conducted in specified branches of 3 different banks in Pakistan. It must not generalize to other banks and their branches. Further the sample size of the study was 250 customers of bank. For future studies other dimensions of SERVQUAL may be test the result of the current study can be compared with the other studies to be undertaken. The number of banks and branches increase for further studies. The sample size will increase and different prospects will be used for study. Further ATM Service Quality, customer satisfaction, customer retention, intention to switch cost and customer loyalty will be investigated.

\section{References}

Al-Hawari, M. \& Ward, T. (2006).The impact of automated service quality on financial performance and the mediating role of customer retention. Journal of Financial Service Marketing, 10(3), 228-43.

Allen, F., McAndrews, J. \& Strahan, P. (2001). E-finance: An Introduction, Working Paper No. 01-36, Financial Institutions Center, Wharton University, Philadelphia, PA, 7 October,

Alshurideh, M. \& ELSamen, A. A. (2012). The Impact of Internal Marketing on Internal Service Quality: A Case Study in a Jordanian Pharmaceutical Company. International Journal of Business and Management, $7(19)$.

Anderson, E. A. \& Sullivan, M. W. (1993).The antecedents and consequences of customer satisfaction for firms. Marketing Science, 12, 125-43.

Bansal, H. \& Taylor, S. (1999). The service switching model (SSM): a model of switching behavior in services industries. Journal of Service Research, 2(2), 200-218.

Bauer, H. H., Hammerschmidt, M. \& Falk, T. (2005). Measuring the quality of e-banking portals. International Journal of Bank Marketing, 23(2), 153-175.

Brady, M., Cronin, J. \& Brand, R. (2002). Performance-only measurement of service quality: a replication and extension. Journal of Business Research, 55, 17-31.

Collier, E. \& Bienstock, C. (2006). Measuring service quality in e-retailing. Journal of Service Research, 8(3), 260-75.

Fassnacht, M. \& Koese, I. (2006). Quality of electronic services: conceptualizing and testing a hierarchical model. Journal of Service Research, 9(1), 19-37.

Fornell, C. (1992). A national customer satisfaction barometer: the. Swedish experience. J. Mark., 56, 6-21.

Fullerton, G. \& Taylor, S. (2002). Mediating, interactive and non-linear effects in service quality and satisfaction with services research. Canadian Journal of Administrative Sciences, 19(2), 124-136.

Ibrahim, E. E., Joseph, M. \& Ibeh, K. I. N. (2006). Customers' perception of electronic service delivery in the UK retail banking sector. International Journal of Bank Marketing, 24(7), 475-493.

Jamal, A. \& Naser, K. (2002). Customer satisfaction and retail banking: an Assessment of Some of the Key Antecedents of Customer Satisfaction in Retail Banking. International Journal o Bank Marketing, 20(4), 146-160.

Joseph, M. \& Stone, G. (2003). An empirical evaluation of US bank customer perceptions of the impact of technology on service delivery in the banking sector. International Journal of Retail and Distribution Management, 31(4), 190-202. 
Kandampully, J. (1998). Service Quality to service loyalty: a relationship which goes beyond customer services. Total Quality Management \& Business Excellence, 9(6), 431-443.

Katono, I. W. (2011). Student evaluation of e-service quality criteria in Uganda: the case of automatic teller machines. International Journal of Emerging Markets, 6(3), 200 - 216.

Khan, A. M. (2010). An Empirical Study of Automated Teller Machine Service Quality and Customer Satisfaction in Pakistani Banks. European Journal of Social Sciences, 13(3).

Lee, G. G. \& Lin, H. F. (2005). Customer perceptions of e-service quality in online shopping. International Journal of Retail and Distribution Management, 33(2), 161-176.

Levesque, T. \& McDougall, G. (1996). Determinants of customer satisfaction in retail banking. International Journal of Bank Marketing, 14(7), 12-20.

Mittal, V. \& Kamakura, W. A. (2001). Satisfaction, Repurchase Intent, and Repurchase Behavior: Investigating the Moderating Effect of Customer Characteristics. Journal of Marketing Research, 38(1), 131-142.

Mosahab, R., Muhammad, O. \& Ramay, T. (2010). Service Quality, Customer Satisfaction and Loyalty: A Test of Mediation. International Business Research, 3(4).

Mols, N. (2000). The internet and service marketing-the case of Danish retail banking. Internet research. Electronic Networking Applications and Policy, 10(1), 7-18.

Narteh, B. (2013). Service quality in automated teller machines: an empirical investigation. Managing Service Quality, 23(1), 62-89.

Pahwa, M. S. \& Saxena, K. (2011). Analytical Study of Customer Satisfaction at ICICI Bank with special reference to ATMs, 2011 3rd International Conference on Information and Financial Engineering IPEDR 12 (2011) (C) (2011) IACSIT Press, Singapore.

Parasuraman, A. \& Zinkhan, G. M. (2002). Marketing to and serving customers through the internet: an overview and research agenda. Journal of the Academy of Marketing Science, 30, 286-295.

Parasuraman, A., Berry, L. \& Zeithaml, V. (1991). Refinement and reassessment of the SERVQUAL scale. Journal of Retailing, 67(4), 420-450.

Parasuraman, A., Zeithaml, V. \& Malhotra, A. (2005). E-S-QUAL: A Multiple-Item Scale for Assessing Electronic Service quality. Journal of Service Research, 7(3), 213-234.

Parasuraman. A., Zeithaml, V. \& Berry, L. (1985). A conceptual model of service quality and its implication for future research. Journal of Marketing, 49, 41-50.

Parasuraman, A., Zeithaml, V. A. \& Berry, L. L. (1988). SERVQUAL, a multiple item scale for measuring consumer perception of service quality. Journal of Retailing, 64(1), 12-40.

Premalatha, J. R. \& Sundaram, N. (2012). Analysis of Customer Satisfaction with reference to ATM Services in Vellore District. IJEMR, 2(2). - Online - ISSN 2249 - 2585 - Print - ISSN 2249 - 8672.

Roos, I. (1999). Switching processes in customer relationships. Journal of Service Research, 2(1), 68-85.

Rust, R., Zahorik, A. \& Keiningham, T. (1995). Return on quality (ROQ): making service quality financially accountable. Journal of Marketing, 59(2), 58-70.

Santos, J. (2003). E-service quality: a model of virtual service quality dimensions. Managing Service Quality, 13(3), 233-246.

Sureshchandar, G., Rajendran, C. \& Anantharaman, R. (2002).The relationship between service quality and customer satisfaction - a factor-specific approach. Journal of Services Marketing, 16(4), 363-79.

Wolfinbarger, M. \& Gilly, M. C. (2003). ETailQ: dimensionalizing, measuring and predicting retail quality. Journal of Retailing, 79, 183-198.

Wu, J. H. \& Wang, Y. M. (2007). Measuring ERP success: the key-users' viewpoint of the ERP to produce a viable IS in the organization. Computers in Human Behavior, 23(3), 1582-96.

Zeithaml, V., Berry, L. \& Parasuraman, A. (1996). The behavioral consequences of service quality. Journal of Marketing, 60(2), 31-46. 